\title{
Math Usage by Practicing Engineers: What does it mean to Curriculum Planners?
}

\author{
Mike Ellis, Brian Williams, Habib Sadid, Ken W. Bosworth, and Larry Stout \\ Idaho State University
}

\begin{abstract}
Engineering programs are constantly assessing the material required to earn an engineering degree. This assessment leads to squeezing in additional courses, often at the expense of requiring additional credits beyond that for a typical Bachelors degree. The common practice of including new material while not changing what already exists is pushing the number of required credits for an engineering degree in excess of what should be expected. A fundamental question not typically addressed is "What material should be removed from the old curriculum in order to make way for new material?" One possible method for addressing this question is to compare what is taught in academia versus what is needed by a practicing engineer. Faculty in the College of Engineering at Idaho State University have developed, administered, and analyzed a survey asking practicing engineers their usage and required conceptual understanding of certain math topics to perform their job functions. It was decided at this time to focus only on the math topics and leave the remainder of the engineering programs for future efforts. Although the survey participants are centered on the geographic area of Idaho State University (south-eastern Idaho), the topics covered in core math courses are typical of what is taught at other universities. This paper presents the results of this survey, discusses some of challenges encountered in conducting this type of evaluation, as well as some conclusions that can be supported from the data.
\end{abstract}

Introduction

A National Science Foundation report expressed the following perspective on engineering education reform: "We need processes whereby curricula within existing departments can be renewed more rapidly. In addition, we need processes for more dramatic change, enabling curricula to adapt quickly to societal needs, analogous to "flexible and agile" manufacturing techniques. Just as we need mechanisms for quickly assembling new programs we need mechanisms for disassembling them when their time is past " 1 .

The United Kingdom recently established a Learning and Teaching Support Network (LTSN). The aim of the LTSN is to provide support to academics in order to improve the provision of learning and teaching. In 2001 the LTSN Subject Centre conducted a needs analysis survey of

Proceedings of the 2004 American Society for Engineering Education Annual Conference \& Exposition Copyright (C) 2004, American Society for Engineering Education 
both industry and academia. There were 410 responses from industry and 315 responses from academia. This survey data suggests that: "The difference in the profile of the engineering graduate as demanded by industry and as supplied from academic appears to be getting greater and greater. " 2

The lack of institutional mechanisms to identify and disassemble obsolete curriculum is a barrier to substantial engineering curriculum reform. A first step in this process is developing an assessment tool to identify curriculum material that is no longer relevant. All engineering programs that are accredited by Accreditation Board for Engineering and Technology (ABET) must have a continuing assessment process ${ }^{3}$. The assessment process must demonstrate that the defined outcomes of the program are being measured. The most commonly adopted assessment tools to satisfy these requirements are employer and alumni surveys. These survey instruments can effectively identify curriculum weakness and omissions; however they generally do not focus attention on areas of the curriculum that may have become obsolete. Employer and alumni surveys are designed to answer the question: What education or skills do graduates need to be successful in today's market? The question that remains unanswered by these survey instruments is: What material is currently in the curriculum that is no longer relevant to current practice?

In 2003 the engineering faculty at Idaho State University (ISU) began a comprehensive assessment of the relevancy of the current curriculum to the engineering profession. A literature search revealed very little published data directly relating the curriculum material to the needs of the profession. Therefore, the faculty at ISU pioneered a survey to collect this type of data. It was also felt that a small pilot survey should be conducted to identify the pertinent issues related to this new type of assessment. The first area that was selected for evaluation was the math courses that are common to most engineering disciplines.

This survey attempts to determine the math curriculum that is most relevant to the engineering profession. But perhaps more significant were the challenges that were encountered in defining a instrument to collect and interpret this data. This paper will discuss the design of the survey instrument, the survey results, and some of the challenges and conclusions that can be extrapolated from the data.

\section{Survey Design}

The objective of this survey is to assess the relevancy of the current math curriculum to the needs of the current practice of engineering. Thus, this survey asked working engineers to describe their usage of the math curriculum material to successfully fulfill their job functions. The current curriculum at Idaho State University is built on an interdisciplinary core of engineering courses. All engineering majors are required to take these core courses. Consequently, the primary objective of this survey was to evaluate the relevancy of the core math courses for all engineering disciplines. The core mathematics courses that were included in the survey are: Calculus I, Calculus II, Differential Equations, and Numerical Analysis of Engineering of Engineering Problems. Consequently, the math curriculum included in this survey does not include all the math courses that may be required for each engineering discipline.

Proceedings of the 2004 American Society for Engineering Education Annual Conference \& Exposition Copyright (C) 2004, American Society for Engineering Education 
The faculty also wanted to determine if there were significant differences in the math usage based on type of job function, engineering discipline, terminal degree, and number of years employed. The respondents were asked to respond to four questions in an effort to collect some profile data to permit the responses to be categorized in this manner. First respondents were asked to define their primary job function from a list of five choices: Design, Test, Analyst, Management, or Other. Next the respondents were asked to declare their engineering discipline as either: Electrical, Civil, Mechanical, Nuclear, or Other. Respondents were then asked to declare their terminal engineering degree: Bachelors, Masters, or Doctorate. Finally, the respondents were asked how many years they had been employed as engineers.

To construct a list of math topics to be included in the survey, the faculty simply took the textbooks that are used in the undergraduate engineering program's required math courses and constructed a list of the topics from the table of contents of each text. Since most courses have required textbooks this was a rather straightforward approach to defining the content of the survey. It should also be noted that although no one textbook is used at all universities, the topics included in different undergraduate texts are generally very similar.

The data collection was separated into two parts. The first part of the survey was designed to assess the usage of the selected math topics by practicing engineers. The second part was designed to assess if a basic conceptual understanding of the mathematical concepts is required to perform the respondent's job functions. It was felt by the faculty that although a particular job may not require an engineer to be proficient in the use of some mathematical calculation techniques some conceptual understanding may be required. The faculty wanted to assess both actual usage of mathematical material and required understanding of the underlying concepts.

In the first part of the survey the respondent was given a math topic such as "differentiation". He or she was then asked to declare the usage of this topic in their present position with one of the following choices: Never, Seldom, or Frequently.

In the second part of the survey respondents were asked to indicate if a basic conceptual understanding of a given math topic is required to perform their job functions. The respondent was asked to respond with either "yes" or "no" to each topic. A "yes" response indicates that some conceptual understanding is required, while a "no" response indicates no understanding is required.

The survey was administered to two different groups: the members of Idaho State University's College of Engineering Advisory Board and recent alumni of the College of Engineering. Each member of the advisory board also solicited responses from several other engineers in their organizations. These responses represent about half of the total responses. The remaining survey responses are from ISU alumni from the past five years. 
Survey Results

A total of 96 engineers responded to our math usage survey. The responses are tabulated in tables 1 through 3. The data are sorted by the "Frequently" and "Yes" responses.

\begin{tabular}{|c|c|c|c|c|c|c|c|}
\hline \multicolumn{8}{|c|}{ Table 1. Profile of Respondents } \\
\hline \multicolumn{2}{|c|}{$\begin{array}{c}\text { Primary Job } \\
\text { Function }\end{array}$} & \multicolumn{2}{|c|}{$\begin{array}{c}\text { Engineering } \\
\text { Discipline }\end{array}$} & \multicolumn{2}{|c|}{ Terminal Degree } & \multicolumn{2}{|c|}{$\begin{array}{c}\text { Work } \\
\text { Experience }\end{array}$} \\
\hline Design & 39 & Electrical & 25 & Bachelors & 73 & $0-3$ years & 33 \\
\hline Test & 7 & Mechanical & 18 & Masters & 20 & $3-7$ years & 25 \\
\hline Analyst & 13 & Civil & 29 & Doctoral & 3 & $7-10$ years & 3 \\
\hline Management & 20 & Nuclear & 4 & & & $10-20$ years & 17 \\
\hline Other & 17 & Other & 20 & & & $\begin{array}{l}\text { More than } \\
20 \text { years }\end{array}$ & 18 \\
\hline
\end{tabular}

\begin{tabular}{|l|c|c|c|}
\hline \multicolumn{4}{|c|}{ Table 2. Summary of Part I. Math Usage } \\
\hline \multicolumn{1}{|c|}{ TOPIC } & NEVER & SELDOM & FREQUENTLY \\
\hline Numerical Methods & 26 & 45 & 25 \\
\hline Limits and Rates of Change & 22 & 51 & 23 \\
\hline Mean Value Theorem/Curve Sketching & 28 & 45 & 23 \\
\hline 3-D Analytic Geometry and Vectors & 42 & 36 & 18 \\
\hline Differentiation & 39 & 43 & 14 \\
\hline First-Order Differential Equations & 44 & 39 & 13 \\
\hline Integrals & 43 & 40 & 13 \\
\hline Parametric Equations \& Polar Coordinates & 39 & 48 & 9 \\
\hline Laplace Transforms & 63 & 24 & 9 \\
\hline Partial Derivatives & 58 & 30 & 8 \\
\hline Techniques of Integration & 48 & 42 & 6 \\
\hline Vector Calculus & 58 & 32 & 6 \\
\hline Nonlinear Differential Equations & 70 & 20 & 6 \\
\hline Multiple Integrals & 65 & 26 & 5 \\
\hline Infinite Sequences and Series & 66 & 26 & 4 \\
\hline
\end{tabular}




\begin{tabular}{|l|r|c|}
\hline \multicolumn{3}{|c|}{$\begin{array}{c}\text { Table 3. Summary of Part II. Conceptual } \\
\text { Understanding Required }\end{array}$} \\
\hline \multicolumn{1}{|c|}{ Topic } & \multicolumn{1}{c|}{ Yes } & \multicolumn{1}{c|}{ No } \\
\hline Differentiation & 84 & 12 \\
\hline Integration & 82 & 14 \\
\hline Numerical Methods & 77 & 19 \\
\hline Differential Equations & 66 & 30 \\
\hline Vector Calculus & 50 & 46 \\
\hline Infinite Sequences and Series & 37 & 59 \\
\hline
\end{tabular}

\section{Challenges}

First and foremost it must be stated that the survey respondents are employed primarily in southeast Idaho. Consequently, the sample size is certainly not large enough to draw any general conclusions that would be applicable to all engineering programs in the United States. The sample size was not large enough to have confidence in any noted differences in the responses based on job function, discipline, terminal degree and number of years of work experience. As a matter of interest, some differences in the responses were noted when the data were sorted by job function, discipline, terminal degree and number of years of work experience (see Appendix A).

The results may also be subject to some sampling and measurement error. The sample was not truly random. The respondent's interpretation of "Never, Seldom, and Frequently" is another possible source of error. Perhaps the greatest challenge is relating the data to curriculum planning. For instance, Numerical Methods scored high in usage survey while Infinite Series and Sequences usage was low. It is interesting to note that many numerical methods are based on Infinite Series and Sequences. Is it possible that the respondents were not fully aware of their use of Infinite Series and Sequences? Or is it possible that engineers are using Numerical Methods in a manner that does not require knowledge of Infinite Series and Sequences? These responses highlight that practicing engineers and academics have different perspectives on the curriculum material.

There were not many responses from engineers with $7-10$ years of experience. Our advisory council is made up primarily of engineers with over 10 years of experience. The second population was from the past 5 years alumni. Some of these engineers had less than one year of work experience. In retrospect, it would have been better to include only engineers with at least one year of work experience. Some respondents with limited work experience were not confident in the requirements of their jobs to respond to some of math usage questions in the survey. 
Many respondents were not comfortable in selecting between the choices given for primary job function. It was not uncommon for the respondent to comment that their jobs included several of the functions provided in the selection list. When this occurred the respondent was asked which of the functions occupied most of their time. It became apparent during the administration of the survey that more detailed information relating to job function would have been very valuable. It is also important to determine if respondents with the same type of job provided similar survey responses.

\section{Conclusions}

It is difficult to conclude if the usage of any math topic is below or above that of any other engineering curricula topic without a reliable benchmark for comparison. This will not be possible until more data are collected and analyzed. Math and basic science are certainly the foundation of any engineering program. This fact will not change in the foreseeable future.

Most engineers feel that at least a conceptual understanding of majority of the math topics is required to perform their job functions even though the survey indicates that the actual usage of these same calculation techniques is significantly less. The one possible exception is Infinite Sequences and Series. Several respondents commented that they felt that the math curriculum was also beneficial in teaching them how to logically formulate solutions to problems.

The most significant finding from the survey data was that there are marked differences in the use of certain mathematical concepts by practicing engineers. There is a significant difference in the usage of the top three topics: Numerical Methods, Limits and Rates of Change, and The Mean Value Theorem / Curve Sketching, and all other topics. While the bottom three topics: Nonlinear Differential Equations, Multiple Integrals, and Infinite Sequences and Series, appear to be used significantly less than all other topics. It is also interesting to note the differences in the responses when the data is sorted by the profile categories i.e., Primary Job Function, Engineering Discipline, Terminal Degree, or Work Experience (see Appendix A) .

The greatest difficulty encountered was using the results of this survey as a curriculum-planning tool. The traditional math curriculum is a logical progression of principles and concepts. The survey responses did not always correspond to this logical sequence. Some topics that involve concepts related to or even built on other topics did not yield similar results. This could imply that engineers are using these math topics but seldom need to understand the underlying theory. It could also imply that the respondents are simply not cognizant of all of the mathematical concepts that they are using to perform their jobs. Some of the inconsistencies in the responses imply that the respondents did not recall enough detail about the subject material in the survey to provide a useful evaluation. In either case, this issue needs to be resolved before the survey results can be fully utilized as a curriculum-planning tool.

In an effort to verify the survey results, a similar survey was given to a group of fourteen engineers that are employed in an electrical consulting firm. The engineers employed in this firm were primarily electrical design engineers with 3-7 years of work experience. The results of this secondary data source compare favorably with the results of this survey.

Proceedings of the 2004 American Society for Engineering Education Annual Conference \& Exposition Copyright (C) 2004, American Society for Engineering Education 
It is important that the results of this survey are considered in the broader context of the entire engineering curriculum. The relative importance of the knowledge of mathematics in the engineering curriculum is addressed by a survey conducted by the engineers at the Boeing Company ${ }^{4}$. This much more extensive survey with 420 responses representing fifteen companies, attempts to assign a "level of importance" to some topics related to engineering knowledge and experience. Participates of this survey are mainly mechanical engineers employed in the aerospace and defense-related companies. The relative level of importance assigned to mathematical related concepts is high.

This survey data should not be used in isolation to derive requirements for an engineering curriculum. The reality of curriculum planning is that inclusion of new subject material often means removing existing material. Therefore, we feel that assesses not only the desired program objectives, but also the relevancy of the present curriculum is an important component of the continuous quality refinement of our program. Consequently, a systematic method needs to be refined for making not only decisions regarding proposed course material additions but also the removal of course material when its time is past.

\section{Bibliography}

\footnotetext{
${ }^{1}$ National Science Foundation (1995), "Restructuring Engineering Education: A Focus on Change", A report of an NSF Workshop on Engineering Education, NSF 95-65.

${ }^{2}$ R Eley, S Williamson, and F Lamb (2002), "Desires of Industry, products from academia - Ships that pass in the night?", Proceedings of the 2002 American Society for Engineering Education Annual Conference \& Exposition.

3 “2003 - 2004 Criteria for Accrediting Engineering Programs”, Engineering Accreditation Commission, Accreditation Board for Engineering and Technology, Inc., Baltimore, MD, http://www.abet.org/criteria.html.

${ }^{4}$ James D. Lang, Susan Cruse, Francis D. McVey and John McMasters, "Industry Expectations of New Engineers: A Survey to Assist Curriculum Designers”, Journal of Engineering Education, January 1999, pp. 43 - 51.
}

\section{Biography}

MIKE ELLIS is presently an Associate Professor in the College of Engineering at Idaho State University. Dr. Ellis has taught engineering courses at the university level for over 13 years and held positions in industry as an Electrical Distribution Designer, Power System Analyst and a Test and Start-up Engineer. He graduated from Virginia Polytechnic and State University in 1994 with a PhD in Electrical Engineering. E-MAIL: ellimikl@,isu.edu.

BRIAN WILLIAMS is presently an Assistant Professor in the College of Engineering at Idaho State University. Dr. Williams has taught engineering courses at Idaho State University for 3 years. Prior to coming to the university, Dr. Williams worked in the aerospace and renewable energy industries as a Mechanical Engineer. He graduated from Utah State University in 1997 with a Ph.D. in Mechanical Engineering. E-MAIL: willbria@isu.edu 
HABIB SADID is presently a Professor of Civil Engineering at Idaho State University. Dr. Sadid has taught civil/structural engineering courses at the university for the last 15 years and held a position in industry as an Analyst Engineer. He graduated from Washington State University in 1988 with a Ph.D. in Civil Engineering specialized in structures. E-Mail sadihabi@isu.edu.

Dr. KEN W. BOSWORTH is a Professor of Computer Science (formerly Mathematics) at Idaho State University, College of Engineering. His research interests include wavelet based classification algorithms, semiparametric data smoothing and analysis, and the pedagogy and teaching of applied mathematics.

LARRY STOUT is currently an Assistant Professor in the College of Engineering at Idaho State University. Dr. Stout received his Ph.D. from Arizona State University in 1997 and has worked as a quality and reliability engineer at several semiconductor companies. E-MAIL stoulawr@isu.edu

\section{Appendix A}

The tables below show the survey results for selected profile categories. The first table in the sequence shows the profile of respondents for both the Math Usage and Conceptual Understanding tables that follow. The selection criteria is highlighted in the profile table. The survey responses in the corresponding Math Usage and Conceptual Understanding tables are also sorted by most frequently used topics to least frequently used topics for ease of comparison. The number of responses in some of these categories is not sufficient to support a high degree of statistical confidence in the results.

\begin{tabular}{|l|r|l|r|l|r|l|r|}
\hline \multicolumn{7}{|c|}{ Table A-1. Primary Job Function - Design } \\
\hline $\begin{array}{c}\text { Primary Job } \\
\text { Function }\end{array}$ & \multicolumn{2}{c|}{$\begin{array}{c}\text { Engineering } \\
\text { Discipline }\end{array}$} & \multicolumn{2}{c|}{ Terminal Degree } & \multicolumn{2}{c|}{$\begin{array}{c}\text { Work } \\
\text { Experience }\end{array}$} \\
\hline Design & $\mathbf{3 9}$ & Electrical & 7 & Bachelors & 32 & $0-3$ years & 14 \\
\hline Test & & Mechanical & 7 & Masters & 7 & $3-7$ years & 13 \\
\hline Analyst & & Civil & 16 & Doctoral & 0 & $7-10$ years & 2 \\
\hline Management & & Nuclear & 0 & & & $10-20$ years & 6 \\
\hline Other & & Other & 9 & & & $\begin{array}{l}\text { More than } \\
\text { 20 years }\end{array}$ & 4 \\
& & & & & & \\
\hline
\end{tabular}

Proceedings of the 2004 American Society for Engineering Education Annual Conference \& Exposition Copyright (C) 2004, American Society for Engineering Education 


\begin{tabular}{|l|c|c|c|}
\hline \multicolumn{4}{|c|}{ Table A-2. Math Usage for Primary Job Function - Design } \\
\hline \multicolumn{1}{|c|}{ TOPIC } & NEVER & SELDOM & FREQUENTLY \\
\hline 3-D Analytic Geometry and Vectors & 17 & 13 & 9 \\
\hline Mean Value Theorem/Curve Sketching & 15 & 17 & 7 \\
\hline Numerical Methods & 16 & 16 & 7 \\
\hline Parametric Equations \& Polar Coordinates & 21 & 12 & 6 \\
\hline Laplace Transforms & 28 & 7 & 4 \\
\hline Limits and Rates of Change & 14 & 22 & 3 \\
\hline Integrals & 16 & 20 & 3 \\
\hline Differentiation & 15 & 22 & 2 \\
\hline First-order Differential Equations & 21 & 16 & 2 \\
\hline Vector Calculus & 22 & 15 & 2 \\
\hline Techniques of Integration & 19 & 19 & 1 \\
\hline Infinite Sequences and Series & 28 & 10 & 1 \\
\hline Multiple Integrals & 28 & 10 & 1 \\
\hline Partial Derivatives & 24 & 15 & 0 \\
\hline Nonlinear Differential Equations & 31 & 8 & 0 \\
\hline
\end{tabular}

\begin{tabular}{|l|c|c|}
\hline \multicolumn{3}{|c|}{$\begin{array}{c}\text { Table A-3. Conceptual Understanding for Primary } \\
\text { Job Function - Design }\end{array}$} \\
\hline \multicolumn{1}{|c|}{ Topic } & Yes & No \\
\hline Differentiation & 34 & 5 \\
\hline Integration & 32 & 7 \\
\hline Numerical Methods & 31 & 8 \\
\hline Differential Equations & 25 & 14 \\
\hline Vector Calculus & 22 & 17 \\
\hline Infinite Sequences and Series & 15 & 24 \\
\hline
\end{tabular}




\begin{tabular}{|l|r|l|r|l|r|l|r|}
\hline \multicolumn{7}{|c|}{ Table A-4. Primary Job Function - Management } \\
\hline \multicolumn{1}{|c|}{$\begin{array}{c}\text { Primary Job } \\
\text { Function }\end{array}$} & \multicolumn{2}{c|}{$\begin{array}{c}\text { Engineering } \\
\text { Discipline }\end{array}$} & \multicolumn{2}{|c|}{ Terminal Degree } & \multicolumn{2}{c|}{$\begin{array}{c}\text { Work } \\
\text { Experience }\end{array}$} \\
\hline Design & & Electrical & 6 & Bachelors & 15 & $0-3$ years & 6 \\
\hline Test & & Mechanical & 5 & Masters & 5 & $3-7$ years & 2 \\
\hline Analyst & & Civil & 7 & Doctoral & 0 & $7-10$ years & 0 \\
\hline Management & $\mathbf{2 0}$ & Nuclear & 1 & & & $10-20$ years & 2 \\
\hline Other & & Other & 1 & & & $\begin{array}{l}\text { More than } \\
\text { 20 years }\end{array}$ & 10 \\
\hline
\end{tabular}

\begin{tabular}{|l|c|c|c|}
\hline \multicolumn{5}{|c|}{ Table A-5. Math Usage for Primary Job Function - Management } \\
\hline \multicolumn{1}{|c|}{ TOPIC } & NEVER & SELDOM & FREQUENTLY \\
\hline Mean Value Theorem/Curve Sketching & 7 & 8 & 5 \\
\hline Limits and Rates of Change & 2 & 15 & 3 \\
\hline Numerical Methods & 4 & 13 & 3 \\
\hline Parametric Equations \& Polar Coordinates & 6 & 12 & 2 \\
\hline 3-D Analytic Geometry and Vectors & 9 & 9 & 2 \\
\hline Differentiation & 13 & 5 & 2 \\
\hline Integrals & 13 & 5 & 2 \\
\hline Infinite Sequences and Series & 17 & 1 & 2 \\
\hline Nonlinear Differential Equations & 17 & 1 & 2 \\
\hline First-order Differential Equations & 12 & 7 & 1 \\
\hline Techniques of Integration & 15 & 4 & 1 \\
\hline Partial Derivatives & 15 & 5 & 0 \\
\hline Multiple Integrals & 15 & 5 & 0 \\
\hline Laplace Transforms & 16 & 4 & 0 \\
\hline Vector Calculus & 17 & 3 & 0 \\
\hline
\end{tabular}




\begin{tabular}{|l|c|c|}
\hline \multicolumn{3}{|c|}{$\begin{array}{c}\text { Table A-6. Conceptual Understanding Required for } \\
\text { Primary Job Function - Management }\end{array}$} \\
\hline \multicolumn{1}{|c|}{ Topic } & Yes & No \\
\hline Numerical Methods & 18 & 2 \\
\hline Differentiation & 17 & 3 \\
\hline Integration & 17 & 3 \\
\hline Differential Equations & 12 & 8 \\
\hline Vector Calculus & 7 & 13 \\
\hline Infinite Sequences and Series & 5 & 15 \\
\hline
\end{tabular}

\begin{tabular}{|l|r|l|l|l|r|l|r|}
\hline \multicolumn{7}{|c|}{ Table A-7. Engineering Discipline - Mechanical } \\
\hline \multicolumn{2}{|c|}{$\begin{array}{c}\text { Primary Job } \\
\text { Function }\end{array}$} & \multicolumn{2}{c|}{$\begin{array}{c}\text { Engineering } \\
\text { Discipline }\end{array}$} & \multicolumn{2}{|c|}{ Terminal Degree } & \multicolumn{2}{c|}{$\begin{array}{c}\text { Work } \\
\text { Experience }\end{array}$} \\
\hline Design & 7 & Electrical & & Bachelors & 14 & $0-3$ years & 9 \\
\hline Test & 0 & Mechanical & $\mathbf{1 8}$ & Masters & 4 & $3-7$ years & 5 \\
\hline Analyst & 2 & Civil & & Doctoral & 0 & $7-10$ years & 0 \\
\hline Management & 5 & Nuclear & & & & $10-20$ years & 3 \\
\hline Other & 4 & Other & & & & $\begin{array}{l}\text { More than } \\
\text { 20 years }\end{array}$ & 1 \\
\hline
\end{tabular}




\begin{tabular}{|l|c|c|c|}
\hline \multicolumn{5}{|c|}{ Table A-8. Math Usage for Engineering Discipline - Mechanical } \\
\hline \multicolumn{1}{|c|}{ TOPIC } & NEVER & SELDOM & FREQUENTLY \\
\hline Limits and Rates of Change & 5 & 8 & 5 \\
\hline 3-D Analytic Geometry and Vectors & 8 & 6 & 4 \\
\hline Integrals & 9 & 5 & 4 \\
\hline Mean Value Theorem/Curve Sketching & 7 & 8 & 3 \\
\hline Numerical Methods & 6 & 9 & 3 \\
\hline Differentiation & 8 & 8 & 2 \\
\hline Vector Calculus & 13 & 3 & 2 \\
\hline Laplace Transforms & 13 & 3 & 2 \\
\hline Parametric Equations \& Polar Coordinates & 8 & 9 & 1 \\
\hline Techniques of Integration & 9 & 8 & 1 \\
\hline First-order Differential Equations & 9 & 8 & 1 \\
\hline Partial Derivatives & 12 & 5 & 1 \\
\hline Multiple Integrals & 12 & 5 & 1 \\
\hline Nonlinear Differential Equations & 14 & 3 & 1 \\
\hline Infinite Sequences and Series & 13 & 5 & 0 \\
\hline
\end{tabular}

\begin{tabular}{|l|c|c|}
\hline \multicolumn{3}{|c|}{$\begin{array}{c}\text { Table A-9. Conceptual Understanding Required for } \\
\text { Engineering Discipline - Mechanical }\end{array}$} \\
\hline \multicolumn{1}{|c|}{ Topic } & Yes & No \\
\hline Differentiation & 17 & 1 \\
\hline Integration & 16 & 2 \\
\hline Numerical Methods & 14 & 4 \\
\hline Differential Equations & 13 & 5 \\
\hline Vector Calculus & 11 & 7 \\
\hline Infinite Sequences and Series & 8 & 10 \\
\hline
\end{tabular}




\begin{tabular}{|l|r|l|l|l|r|l|r|}
\hline \multicolumn{7}{|c|}{ Table A-10. Engineering Discipline - Other } \\
\hline \multicolumn{2}{|c|}{$\begin{array}{c}\text { Primary Job } \\
\text { Function }\end{array}$} & \multicolumn{2}{c|}{$\begin{array}{c}\text { Engineering } \\
\text { Discipline }\end{array}$} & \multicolumn{2}{|l|}{ Terminal Degree } & \multicolumn{2}{c|}{$\begin{array}{c}\text { Work } \\
\text { Experience }\end{array}$} \\
\hline Design & 9 & Electrical & & Bachelors & 17 & $0-3$ years & 2 \\
\hline Test & 0 & Mechanical & & Masters & 1 & $3-7$ years & 10 \\
\hline Analyst & 3 & Civil & & Doctoral & 2 & $7-10$ years & 1 \\
\hline Management & 1 & Nuclear & & & & $10-20$ years & 5 \\
\hline Other & 7 & Other & $\mathbf{2 0}$ & & & $\begin{array}{l}\text { More than } \\
\text { 20 years }\end{array}$ & 2 \\
\hline
\end{tabular}

\begin{tabular}{|l|c|c|c|}
\hline \multicolumn{5}{|c|}{ Table A-11. Math Usage for Engineering Discipline - Other } \\
\hline \multicolumn{1}{|c|}{ TOPIC } & NEVER & SELDOM & FREQUENTLY \\
\hline Mean Value Theorem/Curve Sketching & 4 & 9 & 7 \\
\hline Limits and Rates of Change & 4 & 12 & 4 \\
\hline Parametric Equations \& Polar Coordinates & 7 & 9 & 4 \\
\hline 3-D Analytic Geometry and Vectors & 11 & 5 & 4 \\
\hline Numerical Methods & 3 & 14 & 3 \\
\hline Differentiation & 4 & 13 & 3 \\
\hline First-order Differential Equations & 7 & 10 & 3 \\
\hline Partial Derivatives & 11 & 7 & 2 \\
\hline Integrals & 7 & 12 & 1 \\
\hline Laplace Transforms & 15 & 4 & 1 \\
\hline Techniques of Integration & 7 & 13 & 0 \\
\hline Infinite Sequences and Series & 10 & 10 & 0 \\
\hline Vector Calculus & 13 & 7 & 0 \\
\hline Nonlinear Differential Equations & 13 & 7 & 0 \\
\hline Multiple Integrals & 16 & 4 & 0 \\
\hline
\end{tabular}




\begin{tabular}{|c|c|c|}
\hline \multicolumn{3}{|c|}{$\begin{array}{l}\text { Table A-12. Conceptual Understanding Required for } \\
\text { Engineering Discipline - Other } \\
\end{array}$} \\
\hline Topic & Yes & No \\
\hline Differentiation & 18 & 2 \\
\hline Integration & 17 & 3 \\
\hline Numerical Methods & 17 & 3 \\
\hline Differential Equations & 16 & 4 \\
\hline Vector Calculus & 12 & 8 \\
\hline Infinite Sequences and Series & 10 & 10 \\
\hline
\end{tabular}

\begin{tabular}{|l|r|l|l|l|r|l|r|}
\hline \multicolumn{7}{|c|}{ Table A-13. Engineering Discipline - Civil } \\
\hline $\begin{array}{c}\text { Primary Job } \\
\text { Function }\end{array}$ & \multicolumn{2}{c|}{$\begin{array}{c}\text { Engineering } \\
\text { Discipline }\end{array}$} & \multicolumn{2}{c|}{ Terminal Degree } & \multicolumn{2}{c|}{$\begin{array}{c}\text { Work } \\
\text { Experience }\end{array}$} \\
\hline Design & 16 & Electrical & & Bachelors & 20 & $0-3$ years & 13 \\
\hline Test & 1 & Mechanical & & Masters & 8 & $3-7$ years & 7 \\
\hline Analyst & 3 & Civil & $\mathbf{2 9}$ & Doctoral & 1 & $7-10$ years & 0 \\
\hline Management & 7 & Nuclear & & & & $10-20$ years & 5 \\
\hline Other & 2 & Other & & & & $\begin{array}{l}\text { More than } \\
\text { 20 years }\end{array}$ & 4 \\
\hline
\end{tabular}




\begin{tabular}{|l|c|c|c|}
\hline \multicolumn{4}{|c|}{ Table A-14. Math Usage for Engineering Discipline - Civil } \\
\hline \multicolumn{1}{|c|}{ TOPIC } & NEVER & SELDOM & FREQUENTLY \\
\hline 3-D Analytic Geometry and Vectors & 9 & 13 & 7 \\
\hline Mean Value Theorem/Curve Sketching & 9 & 15 & 5 \\
\hline Numerical Methods & 9 & 16 & 4 \\
\hline Differentiation & 16 & 9 & 4 \\
\hline Limits and Rates of Change & 7 & 19 & 3 \\
\hline Integrals & 14 & 13 & 2 \\
\hline Techniques of Integration & 18 & 9 & 2 \\
\hline Vector Calculus & 18 & 9 & 2 \\
\hline Multiple Integrals & 21 & 6 & 2 \\
\hline Parametric Equations \& Polar Coordinates & 10 & 18 & 1 \\
\hline Partial Derivatives & 17 & 11 & 1 \\
\hline First-order Differential Equations & 18 & 10 & 1 \\
\hline Infinite Sequences and Series & 23 & 5 & 1 \\
\hline Nonlinear Differential Equations & 24 & 4 & 1 \\
\hline Laplace Transforms & 26 & 2 & 1 \\
\hline
\end{tabular}

\begin{tabular}{|l|c|c|}
\hline \multicolumn{2}{|c|}{$\begin{array}{c}\text { Table A-15. Conceptual Understanding Required for } \\
\text { Engineering Discipline - Civil }\end{array}$} \\
\hline \multicolumn{1}{|c|}{ Topic } & Yes & No \\
\hline Integration & 26 & 3 \\
\hline Numerical Methods & 25 & 4 \\
\hline Differentiation & 24 & 5 \\
\hline Differential Equations & 18 & 11 \\
\hline Vector Calculus & 14 & 15 \\
\hline Infinite Sequences and Series & 5 & 24 \\
\hline
\end{tabular}




\begin{tabular}{|l|r|l|r|l|r|l|r|}
\hline \multicolumn{7}{|c|}{ Table A-16. Engineering Discipline - Electrical } \\
\hline \multicolumn{2}{|c|}{$\begin{array}{c}\text { Primary Job } \\
\text { Function }\end{array}$} & \multicolumn{2}{c|}{$\begin{array}{c}\text { Engineering } \\
\text { Discipline }\end{array}$} & Terminal Degree & \multicolumn{2}{c|}{$\begin{array}{c}\text { Work } \\
\text { Experience }\end{array}$} \\
\hline Design & 7 & Electrical & $\mathbf{2 5}$ & Bachelors & 21 & $0-3$ years & 9 \\
\hline Test & 6 & Mechanical & & Masters & 4 & $3-7$ years & 3 \\
\hline Analyst & 2 & Civil & & Doctoral & 0 & $7-10$ years & 2 \\
\hline Management & 6 & Nuclear & & & & $10-20$ years & 3 \\
\hline Other & 4 & Other & & & & $\begin{array}{l}\text { More than } \\
20 \text { years }\end{array}$ & 8 \\
\hline
\end{tabular}

\begin{tabular}{|l|c|c|c|}
\hline \multicolumn{5}{|c|}{ Table A-17. Math Usage for Engineering Discipline - Electrical } \\
\hline \multicolumn{1}{|c|}{ TOPIC } & NEVER & SELDOM & FREQUENTLY \\
\hline Numerical Methods & 8 & 5 & 12 \\
\hline Limits and Rates of Change & 5 & 12 & 8 \\
\hline Mean Value Theorem/Curve Sketching & 7 & 11 & 7 \\
\hline Laplace Transforms & 9 & 11 & 5 \\
\hline First-order Differential Equations & 10 & 11 & 4 \\
\hline Parametric Equations \& Polar Coordinates & 12 & 10 & 3 \\
\hline Integrals & 13 & 9 & 3 \\
\hline Infinite Sequences and Series & 17 & 5 & 3 \\
\hline Differentiation & 11 & 12 & 2 \\
\hline 3-D Analytic Geometry and Vectors & 12 & 11 & 2 \\
\hline Vector Calculus & 13 & 10 & 2 \\
\hline Techniques of Integration & 14 & 10 & 1 \\
\hline Multiple Integrals & 16 & 8 & 1 \\
\hline Partial Derivatives & 18 & 6 & 1 \\
\hline Nonlinear Differential Equations & 19 & 6 & 0 \\
\hline
\end{tabular}




\begin{tabular}{|c|c|c|}
\hline \multicolumn{3}{|c|}{$\begin{array}{l}\text { Table A-18. Conceptual Understanding Required for } \\
\text { Engineering Discipline - Electrical }\end{array}$} \\
\hline Topic & Yes & No \\
\hline Differentiation & 21 & 4 \\
\hline Integration & 19 & 6 \\
\hline Numerical Methods & 17 & 8 \\
\hline Differential Equations & 15 & 10 \\
\hline Vector Calculus & 12 & 13 \\
\hline Infinite Sequences and Series & 11 & 14 \\
\hline
\end{tabular}

\begin{tabular}{|l|r|l|r|l|r|l|r|}
\hline \multicolumn{7}{|c|}{ Table A-19. Work Experience 0-3 Years } \\
\hline \multicolumn{1}{|c|}{$\begin{array}{c}\text { Primary Job } \\
\text { Function }\end{array}$} & \multicolumn{2}{c|}{$\begin{array}{c}\text { Engineering } \\
\text { Discipline }\end{array}$} & \multicolumn{2}{c|}{ Terminal Degree } & \multicolumn{2}{c|}{$\begin{array}{c}\text { Work } \\
\text { Experience }\end{array}$} \\
\hline Design & 14 & Electrical & 9 & Bachelors & 28 & $\mathbf{0 - 3}$ years & 33 \\
\hline Test & 6 & Mechanical & 9 & Masters & 5 & $3-7$ years & \\
\hline Analyst & 0 & Civil & 13 & Doctoral & 0 & $7-10$ years & \\
\hline Management & 6 & Nuclear & 0 & & & $10-20$ years & \\
\hline Other & 7 & Other & 2 & & $\begin{array}{l}\text { More than } \\
\text { 20 years }\end{array}$ & \\
\hline
\end{tabular}




\begin{tabular}{|l|c|c|c|}
\hline \multicolumn{4}{|c|}{ Table A-20. Math Usage for Work Experience 0-3 Years } \\
\hline \multicolumn{1}{|c|}{ TOPIC } & NEVER & SELDOM & FREQUENTLY \\
\hline Limits and Rates of Change & 11 & 15 & 7 \\
\hline Mean Value Theorem/Curve Sketching & 11 & 15 & 7 \\
\hline Numerical Methods & 13 & 14 & 6 \\
\hline 3-D Analytic Geometry and Vectors & 17 & 12 & 4 \\
\hline Differentiation & 19 & 11 & 3 \\
\hline First-order Differential Equations & 17 & 14 & 2 \\
\hline Integrals & 22 & 9 & 2 \\
\hline Techniques of Integration & 19 & 13 & 1 \\
\hline Vector Calculus & 22 & 10 & 1 \\
\hline Multiple Integrals & 25 & 7 & 1 \\
\hline Infinite Sequences and Series & 25 & 7 & 1 \\
\hline Nonlinear Differential Equations & 26 & 6 & 1 \\
\hline Laplace Transforms & 27 & 5 & 1 \\
\hline Parametric Equations \& Polar Coordinates & 18 & 15 & 0 \\
\hline Partial Derivatives & 23 & 10 & 0 \\
\hline
\end{tabular}

\begin{tabular}{|l|c|c|}
\hline \multicolumn{3}{|c|}{$\begin{array}{c}\text { Table A-21. Conceptual Understanding Required for } \\
\text { Work Experience 0-3 Years }\end{array}$} \\
\hline \multicolumn{1}{|c|}{ Topic } & Yes & No \\
\hline Numerical Methods & 29 & 4 \\
\hline Differentiation & 28 & 5 \\
\hline Integration & 27 & 6 \\
\hline Differential Equations & 25 & 8 \\
\hline Vector Calculus & 18 & 15 \\
\hline Infinite Sequences and Series & 7 & 26 \\
\hline
\end{tabular}




\begin{tabular}{|l|r|l|r|l|r|l|l|}
\hline \multicolumn{7}{|c|}{ Table A-22. Work Experience More than 20 Years } \\
\hline \multicolumn{2}{|c|}{$\begin{array}{c}\text { Primary Job } \\
\text { Function }\end{array}$} & \multicolumn{2}{c|}{$\begin{array}{c}\text { Engineering } \\
\text { Discipline }\end{array}$} & \multicolumn{2}{|l|}{ Terminal Degree } & \multicolumn{2}{c|}{$\begin{array}{c}\text { Work } \\
\text { Experience }\end{array}$} \\
\hline Design & 4 & Electrical & 8 & Bachelors & 10 & $0-3$ years & \\
\hline Test & 0 & Mechanical & 1 & Masters & 8 & $3-7$ years & \\
\hline Analyst & 3 & Civil & 4 & Doctoral & 0 & $7-10$ years & \\
\hline Management & 10 & Nuclear & 3 & & & $10-20$ years & \\
\hline Other & 1 & Other & 2 & & & $\begin{array}{l}\text { More than } \\
\text { 20 years }\end{array}$ & $\mathbf{1 8}$ \\
\hline
\end{tabular}

\begin{tabular}{|l|c|c|c|}
\hline \multicolumn{4}{|c|}{ Table A-23 Math Usage for Work Experience More than 20 Years } \\
\hline \multicolumn{1}{|c|}{ TOPIC } & NEVER & SELDOM & FREQUENTLY \\
\hline Numerical Methods & 3 & 9 & 6 \\
\hline 3-D Analytic Geometry and Vectors & 7 & 6 & 5 \\
\hline Limits and Rates of Change & 2 & 12 & 4 \\
\hline Parametric Equations \& Polar Coordinates & 5 & 9 & 4 \\
\hline Mean Value Theorem/Curve Sketching & 7 & 7 & 4 \\
\hline Differentiation & 7 & 8 & 3 \\
\hline First-order Differential Equations & 7 & 8 & 3 \\
\hline Integrals & 7 & 8 & 3 \\
\hline Nonlinear Differential Equations & 11 & 4 & 3 \\
\hline Techniques of Integration & 9 & 7 & 2 \\
\hline Partial Derivatives & 10 & 6 & 2 \\
\hline Infinite Sequences and Series & 14 & 2 & 2 \\
\hline Multiple Integrals & 9 & 8 & 1 \\
\hline Laplace Transforms & 10 & 7 & 1 \\
\hline Vector Calculus & 10 & 8 & 0 \\
\hline
\end{tabular}




\begin{tabular}{|l|c|c|}
\hline \multicolumn{3}{|c|}{$\begin{array}{c}\text { Table A-24. Conceptual Understanding Required for } \\
\text { Work Experience More than 20 Years }\end{array}$} \\
\hline \multicolumn{1}{|c|}{ Topic } & Yes & No \\
\hline Numerical Methods & 15 & 3 \\
\hline Differentiation & 15 & 3 \\
\hline Integration & 15 & 3 \\
\hline Differential Equations & 9 & 9 \\
\hline Vector Calculus & 9 & 9 \\
\hline Infinite Sequences and Series & 7 & 11 \\
\hline
\end{tabular}

